\title{
CULTIVATION OF COTTON IN CHINA AND IRAN WITH CONSIDERING BIOLOGICAL ACTIVITIES AND ITS HEALTH BENEFITS
}

\author{
W. SUN ${ }^{1}$, M.H. SHAHRAJABIAN ${ }^{1,2^{*}}$, M. KHOSHKHARAM ${ }^{2}$, \\ H. SHEN ${ }^{3}$, Q. CHENG ${ }^{1,4 *}$
}

^E-mail: chengqi@caas.cn; hesamshahrajabian@gmail.com

Received: Mar. 21, 2020. Revised: May, 05, 2020. Accepted: May 11, 2020. Published online: June 5, 2020

\begin{abstract}
Cotton (Gossypium L.) is one of the most important commercial crops and it is famous as white gold. Cotton has a diversity of applications, principally medicinal and many other usages, such as pigments, derivatives for cattle feed, different uses of the oil extracts and etc. Cottonseed oil has a ration of $2: 1$ of polyunsaturated to saturated fatty acids and generally consists of $65-70 \%$ unsaturated fatty acids, including 18-24\% monounsaturated (oleic) and $42-52 \%$ polyunsaturated (linoleic), and 26-35\% saturated (palmitic and stearic). The most important health benefits of cotton is treat respiratory diseases, treat skin problems, treat wounds, beneficial for breastfeeding mothers, a good cure for rat bite, an appropriate cure for scorpion bite, for
\end{abstract}

joint and eye pains, for swollen legs, for removing bacteria in teeth, and alternative medicine for various diseases such as cancer, HIV and etc. Cotton seed oil mostly extracted from Gossypium hirsutum and Gossypium herbaceum, that are also grown for cotton fiber and animal feed. Gossypol is one of the most effective ingredients, both in traditional pharmaceutical practices and alternative modern medicinal preparations. It is a toxic polyphenolic bisesquiterpene, which may have antifertility and antiviral properties. The obtained findings suggest potential of cotton as a natural resource in pharmaceutical industries.

Keywords: gossypol; oil; Traditional Chinese Medicine; Traditional Iranian Medicine.

\footnotetext{
${ }^{1}$ Biotechnology Research Institute, Chinese Academy of Agricultural Sciences, Beijing, China

${ }^{2}$ Faculty of Agriculture, Islamic Azad University, Isfahan (Khorasgan) Branch, Isfahan, Iran

${ }^{3}$ NMPA Key Laboratory for Testing and Risk Warning of Pharmaceutical Microbiology, Biological Inspection Department, Zhejiang Institute for Food and Drug Control, Hangzhou, China

${ }^{4}$ College of Life Sciences, Hebei Agricultural University, Baoding, Hebei, China; Global Alliance of HeBAUCLS\&HeQiS for BioAl-Manufacturing, Baoding, Hebei, China
} 


\section{W. SUN, M.H. SHAHRAJABIAN, M. KHOSHKHARAM, H. SHEN, Q. CHENG}

\section{INTRODUCTION}

Cotton ranked seventh in the world cultivated area and genetically modified cotton is the third most planted biotech crop worldwide (James, 2012). Cotton also is the only crop that did not acquire its value by being a staple food (Wendel et al., 2010). Gossypium arboretum is only known in cultivation and its origin is uncertain. It may have developed from Gossypium herbaceum L., though molecular comparisons support the hypothesis that Gossypium arboretum and Gossypium herbaceum diverged from a common ancestor. Gossypium arboretum has been cultivated in Asia for many centuries. It is still found there, but has mostly been replaced by Gossypium hirsutum L. From Asia Gossypium arboretum was brought to Sudan, and from there it spread to West Africa. Nowadays it is cultivated mainly in the drier parts of India and Pakistan, and sometimes in tropical Africa, where it has occasionally naturalized (Fryxell, 1979). In tropical Africa it is common in yards and abandoned dwelling sites (Seagull and Giavalis, 2004; Stetina et al., 2014; Bellaloui et al., 2015). Cotton is one of the world's leading agricultural crops, is plentiful and economically produced, making cotton products relatively inexpensive (Wilkins and Arpat, 2005; Stetina et al., 2014). Cotton originated in the African and Asian continents, and has been used for textile making for thousand years. Fragments of cloth from the Indus Valley Civilization in Pakistan show that the people living there aroung $3500 \mathrm{BC}$ knew how to weave cotton into cloth. The first written mention of cotton was the Rig Veda written around 1500 BC (Khadi et al., 2010). The most important chemical constituents of cotton are alkaloids, phenolic compounds, terpenoids, tannins, saponins, flavonoids, cardiac glycosides and protein (Buser, 2001; Hedge et al., 2004; Knox et al., 2006; Ezuruike and Prieto, 2014). Both China and India are two of the world's largest producers and consumers of food and other agricultural products.

\section{Cultivation in China}

Cotton is the leading cash crop in China (Koondhar et al., 2018). The cotton sown area accounts for about $30 \%$ of the total sown area of all various cash crops. It is the main material used in the textile industry in China. More than $95 \%$ of textile materials were cotton during the 1950 's, and it still occupies $80 \%$ at present. There are some problems concerning rational location of cotton production in China. In order to solve the problems existing in civil cotton and supply, in view of strategy, a number of cotton production bases must be selected and built step by step in a planned way. The location of cotton production should be adjusted progressively in accordance with existing problems. The existing cotton production regions should be consolidated and improved. The cotton production region of the middle and lower reaches of the Huang He river should be renewed 


\section{CULTIVATION OF COTTON IN CHINA AND IRAN}

quickly to make it become the largest stable and high-yield cotton production region. In the regions with suitable natural conditions and large water and soil potential, new cotton production regions should be developed in a planned way. In the regions where natural conditions are unsuitable or the competition between grain and cotton is sharp, cotton maybe replaced by grain and other crops. In the self-supporting regions one should raise the yield per unit areas, not exparde the fields (Zhu, 1991).

\section{Cultivation in Iran}

China, India, Pakistan, United States, Uzbekistan, and Brazil are main cotton producer countries and Iran with annual production of nearly 253604 tons was the 19th country in the world cotton production. Total cotton harvested area in 2009 for Iran was almost 105370 ha with average yield of 2.4 tons per hectare, and the highest production belonged to Khorasan-Razavi and KhorasanJonobi province with production of 100503 and 33907 tons, respectively, Alborz province cotton production is 8052 with average yield of 4.9 tons per hectare (Pishgar-Komleh et al., 2012). The shares of energy inputs for cotton production is shown in Figure 5.? China is one of the largest cotton producing country in the world, and among 31 provinces in mainland China, 24 provinces produce cotton and about 300 million people are involved in cotton production. Cotton is one of the most important cash crops in China and cotton is a pillar agricultural commodity in many regions and benefits a large rural population (UNEP, 2002). Xinjiang leads in agricultural outputs in China, especially cotton production (Scull, 2008). Appiah et al. (2014) have suggested new policies maybe introducing incentives for farmers to use natural resources in a more sustainable way to maintain a sustainable agricultural production, especially cotton production in Xinjiang and an integrated framework of policies for production, natural resources and environment is required.

\section{Cultivation and sustainability}

Mollaee et al. (2019) revealed that cotton (Gossypium hirsutum L.) is currently grown in 100 countries and fulfills one third of the global demand for natural fiber. Irrespective of production regions, cotton production across the world is constrained by the high incidence of pests and diseases, weed pressure and evolution of herbicide resistance in weeds, salinity and soil degradation, and climate aberrations such as drought, floods, and heat waves. Crop production potentials and constraints can vary with countries. Introduction of genetically modified (GM) cotton and its adoption by major producing countries have changed the global trends in cotton production. Although adoption of GM cotton has ensured a reduction in the usage of insecticides and improved in broad spectrum weed control due to the flexibility in 
herbicide based weed management, sustainability of GM cotton could be challenged by the evolution of resistance in insects and weed biotypes. Enhanced adoption of commercially available GM cotton may narrow down the existing genetic diversity of cotton varieties. To ensure sustainability, there should be crop improvement programs by diversifying the genetic base of cotton varieties to handle any biotic and abiotic stresses and a future change in climate. Current management practices of cotton include frequent tillage, which limit a complete adoption of conservation agriculture systems and overhead systems of irrigation. The use of cover crops and narrow row spacing may minimize tillage with the additional benefits of reduced weed pressure, improved soil health and a reduction in soil compaction and degradation. Modeling studies could help to forecast and minimize different production constraints; however, modeling approaches should bring a holistic picture considering different aspects of crop production rather than isolated scenarios. More avenues also exist for the efficient utilization of by products. In a nutshell, science and technology should work hand in hand to minimize the uncertainties and explore more avenues for a profitable, environment friendly and sustainable cotton production system.

Radhakrishnan (2017) found that sustainability is an objective that refers to the environment and economic and social issues of any culture. Cotton farming systems are diverse and the issues associated with cotton cultivation vary owing to environmental, agro-ecological, climatic, socioeconomic and political situations. The role of biotechnology in cotton farming is important in producing durable hybrids and reducing the amount of insecticides and fertilizers. Global standards have been instituted to cultivate organic crops and voluntary sustainability initiatives assess many sustainability issues in cotton production. The cotton industry reaches out to all involved, from small poverty-stricken farmers to chic fashion stores in different parts of the globe. There is a call for a mass-market transformation in which sustainable cotton is the norm and for a change in global perspectives and the emergence of sustainable strategies to improve the livelihood of 250 million families involved in producing this valuable crop. Cotton production contributes considerably to Uzbekistan's export earnings.

The various reforms implemented to increase the operational autonomy of agricultural producers considered the stability of cotton production, yet often at the expense of farm incomes. Options for improving the farm incomes can be achieved through modifications of the cotton policy settings. Such options are analyzed by replacing the present area-based yield prescriptions by tradable cotton targets between cotton-growing farms. The net benefits would increase due to the difference in land fertility and 


\section{CULTIVATION OF COTTON IN CHINA AND IRAN}

location to irrigation canal between contracted farms. However, the sustainability of such policy modifications would depend on strong mechanisms for price negotiation and conflict resolution (Shavkat and Djanibekov, 2015). China has also been giving consideration to how it can sustain it supply of cotton given current demands on the use of its agricultural land, particularly to grow food. Once strategy has been to increasingly locate its cotton production in its northwest, especially in Xinjiang (Zhao and Tisdell, 2009).

If the Chinese economy continues to grow and develop at a fast pace, this is likely to result in significant structural change in Chinese agriculture as rural-to-urban migration continues. In turn, this may result in changes that favor merging of farms and greater mechanization in agriculture, that is a trend towards more industrial-type specialized farms. The long term implications of such changes for China's cotton industry are unclear but they may result in a decline in cotton production in all regions of China, except in its northwest. Interestingly, the supply of cotton from China has continued increasing despite the economic and environmental difficulties which its cotton-growers face. The depth and nature of these difficulties vary between the major cotton-producing regions of China. Another point is water is in short supply in the Yellow River Region and almost all the available water resources have been utilized in Northwest regions of
China. Besides, will less agricultural labour available in China, there are likely to be economic pressures to increasingly mechanize and adopt more capital-intensive techniques for agricultural production, raise the size of farms and import agricultural produce rather than rely as heavily as in the past on domestic production. These complex economic changes may make it very difficult for China to sustain the level of its cotton production in the long term.

Cotton production in the northern part of Ghana has contributed so much to the economic development of the inhabitants and the textile industry as a whole. It has been a source of livelihood for many if not all. Over the years, issues concerning cotton have been of great concern and sensitive to the government and people of the north. This paper therefore, seeks to explore the history behind cotton cultivation in northern Ghana, mode of marketing, the challenges confronting the sector and the prospects it holds for the Ghanaian textile industry. Information relevant to this study was gathered through interview, using descriptive case study research design approach to assess the phenomena of then and now of cotton production in Ghana. The study has shown that the cotton sector when well organized will provide income for folks in northern Ghana and invariably provide raw materials for the Ghanaian textile industry. It identifies the major setbacks militating against cotton cultivation in Ghana and 


\section{W. SUN, M.H. SHAHRAJABIAN, M. KHOSHKHARAM, H. SHEN, Q. CHENG}

recommendations for the way forward. The bottlenecks identified include poor farmer organization, lack of farm inputs, research into improved seeds and new technology in the cultivation of cotton (Asinyo et al., 2019).

Ethiopia is one of the African countries that produce and export cotton. It has a long tradition of cotton cultivation with an estimated area of 2.6 million hectares suitable for this product. Of these, $65 \%$ is found in 38 high potential cotton producing areas and the remaining 0.9 million hectares or $35 \%$ is in 75 medium potential districts. Of the total land under cotton cultivation, $33 \%$ is cultivated by small holders, $45 \%$ by private farms and $22 \%$ are state owned farms. But, Ethiopia shares only $5 \%$ of total cotton produced in Africa. This is because it recently cultivates only $3 \%$ of the total suitable land for cotton production. Ethiopia produces an average of $33,842.11$ metric tonnes in the year 2000-2018. The production trend shows some declining stage since 2012. Natural and technological constraints were existed for cotton production in this country. The country also participates on the export market and earned an average of $\$ 14,336,667$, especially in the last decade. Currently the country exports with an average price of $\$ 1.45$. Cotton market has also some constraints like price disincentives and lack of market information. Despite its inefficiency the cotton sector still has its own vital economic role on textile industry and employment creation. It employs about 52,754 smallholder farmers. Therefore, it is recommended that the government, the producers and other relevant stakeholders should work in collaboration to solve the constraints (Zeleke et al., 2019).

Bt cotton was among the first transgenic crops to be used in commercial agriculture. A gene from the soil bacterium Bacillus thuringiensis $(\mathrm{Bt})$ has been transferred to the cotton genome. This gene codes for production of a protein that is toxic to the cotton bollworms, severe insect pests in most cotton-growing regions of the world. In the United States and China, Bt cotton was commercialized in the mid-1990s, and today, the technology covers around $30-40 \%$ of the cotton area in both countries. Recent studies demonstrate that US and Chinese Bt adopters realize significant pesticide and cost savings. In 1996, Mexico and the United States became the first two countries to plant $\mathrm{Bt}$ cotton commercially. Bt cotton reduces use of insecticides, cuts farmers' production costs, and increases yields. Global adoption of $\mathrm{Bt}$ cotton has risen dramatically from 800,000 hectares in its year of introduction in 1996 to 5.7 million hectares (alone and stacked with herbicide-tolerant cotton) in 2003. Significant economic and production advantages have resulted from growing $\mathrm{Bt}$ cotton globally. Bt cotton can substantially reduce the number of pesticide sprayings, which reduces worker and environmental exposure to chemical 


\section{CULTIVATION OF COTTON IN CHINA AND IRAN}

insecticides and reduces energy use. The quality of life for farmers and their families can be improved by the increased income and time savings offered by Bt cotton. These economic, environmental, and social benefits are being realized by large and smallholder farmers alike in eight countries around the world.

Bt cotton was planted on over 15 million hectares in 11 countries in 2009 and has contributed to a reduction of over 140 million kilograms of insecticide active ingredient between 1996 and 2008. It is estimated that between 1996 and 2005 the deployment of Bt cotton has reduced the volume of insecticide active ingredient used for pest control in cotton by 94.5 million kilograms and increased farm income through reduced costs and improved yields by US\$7.5 billion. The efficacy of Bt maize and cotton against major pest species has been associated with an estimated 136.6 million $\mathrm{kg}$ global reduction in insecticide active ingredient used between 1996 and 2006 (29.9\% reduction). Benefits vary by country and region and are heavily weighted towards cotton production, which has historically been one of the largest users of insecticides in the world. Many cotton production strategies (from the pest control point of view) have been applied in cotton production world - wide, these strategies are: 1. Insecticides treatment Strategy (ITS); 2. Integrated pest management (IPM) strategy (IPMS); $3 . \quad$ Pheromone technology strategy (PTS); 4. Sterile insect release (SIR) strategy (SIRS); 5. Biological control strategy (BCS); 6. Bt-transgenic strategy (Bt.S) and Organic strategy (OS). This review focuses on the Bt cotton world use, benefits and production (Albeltagy, 2014).

The main cotton producing countries China and India gave commercial approval for Bt cotton in 1997 and 2002, respectively. Today, $\mathrm{Bt}$ varieties have reached over $50 \%$ of the total cotton area in China. The Bt technology is a mean to control lepidopteran cotton pests, hence offering the possibility to reduce the application of chemical pesticides and lowering production costs. Previous studies, which assess the $\mathrm{Bt}$ technology, claim a sharp reduction in pesticide use accompanied by significant human health and environmental benefits. In these studies, the conclusions on benefits were derived from a comparison between $\mathrm{Bt}$ and non-Bt varieties rather than from an analysis of the pest control effects of $\mathrm{Bt}$ crops. Furthermore, costs of possible longterm ecological effects of Bt crops were not included and, none of the studies has taken into account the uncertainty that underlies the main parameters. Thus, there is a danger that if results from case studies are generalized, wrong conclusions are drawn about prospects, opportunities and constraints of Bt crops on a global scale. The approach presented here complements previous studies by using a stochastic partial budgeting model that captures the key pest 


\section{W. SUN, M.H. SHAHRAJABIAN, M. KHOSHKHARAM, H. SHEN, Q. CHENG}

control properties of $\mathrm{Bt}$ cotton taking into account uncertainty (Pemsl et al., 2003).

\section{Cottonseed oil}

Cottonseed contains hull and kernel. The hull produces fiber and linters, and the kernel contain oil, protein, carbohydrate and other constituents, such as vitamins, minerals, lecithin, sterols and etc. Cottonseed oil is extracted from cotton seed kernel and also termed as heart oil is among the most unsaturated edible oils. It does not need to be as fully hydrogenated for many a cooking purposes as is required in case of some of the more polyunsaturated oils. Cottonseed oil has a ration of 2:1 of polyunsaturated to saturated fatty acids and generally consists of $65-70 \%$ unsaturated fatty acids including $18-24 \%$ monounsaturated (oleic), and $42-52 \%$ polyunsaturated (linoleic) and 26-35\% saturated (palmitic and stearic). Cottonseed oil is described by scientists as being naturally hydrogenated because of the levels of oleic, palmitic, and stearic acids in its.

\section{Cotton in Traditional Iranian, Chinese and Asian Medicines and modern science}

Herbal medicine has long been recognized as one of the oldest forms of remedies used by human beings (Soleymani and Shahrajabian, 2018; Sun et al., 2019a,b,c: Sun et al., 2020a,b,c), and many people in different parts of the world, especially developing countries still rely on traditional healing practices and medicinal plants for their daily health care needs (Khoshkharam et al., 2019; Ogbaji et al., 2018; Shahrajabian et al., 2019a,b; Shahrajabian et al., 2020). In China, Chinese have long known the abortive properties of the plant and its effects on men sperm; however, it was later noted that families who cooked with cottonseed oil had fewer children. Modern medical science has found that parts of the cotton plant may have potential use in the treatment of HIV and cancer. It has been found in one study to have the ability to inhibit cancerous growths in head and neck cancers. Since 1989, potential treatments were tested in vitro to control the human immunodeficiency virus (HIV) to reduce their enzymatic activities (Polska et al., 1989), with (-) gossypol (An et al., 2012). It can be used ingested, as well as vaginal gels for HIV control, in addition to their effect to stop the mobility of sperms that serves as birth control and even to prevent other sexual transmitted diseases, such as herpes (Ratsula et al., 1983). Plants synthesise hundreds of chemical compounds for different functions (Shahrajabian et al., 2019 $\mathrm{c}, \mathrm{d}, \mathrm{e}, \mathrm{f})$.

Chewing the root bark of the cotton plant is supposed to stimulate the sex organs and it has a reputation for being an aphrodisiac. In Ayurvedic medicine and other traditional medicine systems in the Indian subcontinent plants and their parts are used to improve blood circulation, for ear problems, colds, diarrhea and 


\section{CULTIVATION OF COTTON IN CHINA AND IRAN}

gout, as well as a whole host of other ailments. The seeds and leaves are used in Southeast Asia and the subcontinent to treat a variety of health problems, and are used both internally and externally for skin problems and injuries. Powdered cotton seeds mixed with milk are given to those with headaches, and an infusion of the seeds and leaves, which said to be useful for cases of dysentery. Cotton seeds or the expressed juice from the leaves are used to treat skin problems, while the leaves can be made into a poultice for sprains or painful areas of the limbs. The seeds are ground and made into a paste with water and ginger for burns, and an infusion, a mixture of the seeds and leaves and also mustard seeds is used for snake bites and scorpion stings. The fibers can be made into a wide variety of fabrics ranging from lightweight voiles and laces to heavy sailcloths and thick-piled velveteens, suitable for a great variety of wearing apparel, home furnishings, and industrial uses. Cotton fabrics can be extremely durable and resistant to abrasion, and cotton accepts many dyes, is usually washable, and can be ironed at relatively high temperatures. The most important chemical constituents of cotton are alkaloids, phenolic compounds, terpenoids, tannins, saponins, flavonoids, cardiac glycosides and protein. The pharmacological investigations revealed that they possessed antidiabetic, hypolipidemic, antioxidant, anticancer, antidepressant, antiepileptic, memory enhancement, wound healing, nephroprotective, hepatoprotective, antimicrobial, anthelmintic, antiprotozoal, insecticidal, diuretic, gastric ulcer healing and wide range of effects on reproductive systems. Health benefits of cotton included mucus, tannins, flavonoids, essential oil and other substances is shown in Table 1. Traditional uses and benefits of cotton is presented in Table 2. Ayurvedic health benefits of tree cotton is presented in Table 3.

Table 1 - Health benefits of cotton included mucus, tannins, flavonoids, essential oil and other substances

\begin{aligned} \hline $1- &$ Treat respiratory diseases \\ \hline $2- &$ Treat skin problems \\ \hline $3- &$ Treat wounds or inflamed mucus membrane in the respiratory organs \\ \hline $4- &$ Beneficial for breastfeeding mothers \\ \hline $5- &$ Cure for rat bite \\ \hline $6- &$ For scorpion bite \\ \hline $7- &$ For joint pains \\ \hline $8- &$ For swollen legs \\ \hline $9- &$ For eye pains \\ \hline $10- &$ For removing bacteria in teeth \\ \hline $11- &$ For mumps \\ \hline $12- &$ For curing puss in the ears \\ \hline $13- &$ For blood and sticky motions \\ \hline $14- &$ Alternative medicine for various diseases \end{aligned}




\section{W. SUN, M.H. SHAHRAJABIAN, M. KHOSHKHARAM, H. SHEN, Q. CHENG}

Table 2 - Traditional uses and benefits of cotton

\begin{aligned} & \hline 1 - Juice of the root is used in the treatment of fevers \\ & \hline $2-$ Root bark is used as an abortifacient \\ & \hline $3-$ Root decoction is used to prevent abortion \\ & \hline $4-$ Powdered root bark is used to treat lymphatic swellings \\ & \hline $6-$ Fresh leaves of tree cotton are used to treat ulcers \\ & \hline $7-$ It is used for wound dressing and curbing infection \\ & \hline $8-$ It is applied on forehead to relieve headache \\ & \hline $9-$ It cures digestive disorders \\ & \hline $10-$ It encourages proper bile secretion in the liver \\ & \hline $11-$ It helps in uterine contraction \\ & \hline $12-$ It helps in breast enlargement \\ & \hline $13-$ It supports healthy immune system \\ & \hline $14-$ Chewing the root bark of the cotton plant is thought to stimulate the sex organs \\ & and it has a reputation for being an aphrodisiac \\ & \hline $15- \begin{array}{l}\text { Seeds and leaves are used in Southeast Asia and the subcontinent to treat a } \\ \text { variety of health problems, and are used both internally and externally for skin } \\ \text { problems and injuries }\end{array} \\ &$\hline $16-$ Powdered cotton seeds mixed with milk are given to those with headaches \\ & \hline $17-$ An infusion of the seeds and leaves is said to be useful for cases of dysentery \\ & \hline $18-$ Cotton seeds or the expressed juice from the leaves are used to treat skin \\ & problems \end{aligned}

Table 3 - Ayurvedic health benefits of tree cotton

\begin{tabular}{l}
\hline Diarrhea \\
\hline Maturant \\
\hline Leucorrhoea \\
\hline Ear discharge \\
\hline Galactagogue \\
\hline Emacitation \\
\hline Epilepsy \\
\hline Menstrual pain \\
\hline Curing hysteria and fear \\
\hline Burn skin mark removal and healing \\
\hline
\end{tabular}

Gossypol, a poly-phenolic with potential contraceptive effects and trans-caryophyllene, a terpenoid having anti-inflammatory and cytotoxic properties, are examples of compounds present in cotton with potential beneficial impact on humans and animals (Amiel et al., 2012). Egbuta et al. (2017) noted that three major classes of compounds and some primary metabolites have been previously identified in the plant, and among these compounds, most terpenoids and their derivatives (51), 


\section{CULTIVATION OF COTTON IN CHINA AND IRAN}

fatty acids (4), and phenolics (6), were found in the leaves, bolls, stalks, and stems. They have concluded that biological activities, such as antimicrobial and anti-inflammatory activities, are associated with some of these phytochemicals, for example, $\beta$-bisabolol, a sesquiterpenoid enriched in the flowers of cotton plants, may have anti-inflammatory product application.
Considering the abundance of biologically active compounds in the cotton plant, there is scope to develop a novel process within the current cotton fiber production system to separate these valuable phytochemicals, developing them into potentially high-value products. Biological activities of different compounds present in cotton is presented in Table 4.

Table 4 - Biological activities of different compounds present in cotton (Egbuta et al., 2017)

\begin{tabular}{|c|c|}
\hline Compounds & Biological activity \\
\hline \multicolumn{2}{|l|}{ Terpenes } \\
\hline Camphene & Aromatic properties, antioxidants effects \\
\hline Limonene & $\begin{array}{l}\text { Flavouring properties, gastro-protective } \\
\text { effects, anti-cancer and anti- } \\
\text { inflammatory activity }\end{array}$ \\
\hline Myrcene & $\begin{array}{l}\text { Analgesic effects, anti-microbial activity, } \\
\text { anti-inflammatory activity, anti-catabolic } \\
\text { activity }\end{array}$ \\
\hline$\alpha$ and $\beta$-pinene & $\begin{array}{l}\text { Gastro-protective effects, anti-microbial } \\
\text { and anti-inflammatory effects }\end{array}$ \\
\hline Sabinene & $\begin{array}{l}\text { Anti-microbial activity, anti-oxidant } \\
\text { activity }\end{array}$ \\
\hline$\alpha$-thujene & Pungent activity \\
\hline Caryophyllene & $\begin{array}{l}\text { Anti-inflammatory effects, anti-microbial } \\
\text { activity, regulation of cellular lipid } \\
\text { metabolism, flavouring properties }\end{array}$ \\
\hline Farnesene & Anti-oxidant effects \\
\hline Humulene & $\begin{array}{l}\text { Anti-inflammatory properties, aromatic } \\
\text { properties and cytotoxic activity }\end{array}$ \\
\hline Bisabolol & $\begin{array}{l}\text { Aromatic properties, anti-inflammatory } \\
\text { effects, anti-carcinogenic activity, anti- } \\
\text { microbial and anti-oxidative properties }\end{array}$ \\
\hline Caryophyllene oxide & $\begin{array}{l}\text { Cytotoxic activity, phytogrowth } \\
\text { inhibition, analgesic and anti- } \\
\text { inflammatory activity }\end{array}$ \\
\hline 3,10-dihydroxy-1,3,5,7-cadinatetraen-9-one & Phytoalexin, antifungal agent \\
\hline$\beta$-sitosterol & $\begin{array}{l}\text { Antimicrobial activity, anti- } \\
\text { hypercholesterolemic and } \\
\text { anti-inflammatory activity }\end{array}$ \\
\hline Strigol & Germination stimulant \\
\hline $\begin{array}{l}\text { 2,3,9-trihydroxy-1,3,5,7,9-cadinapentaen-14- } \\
\text { al;3-Me ether }\end{array}$ & Phytoalexin \\
\hline
\end{tabular}




\section{W. SUN, M.H. SHAHRAJABIAN, M. KHOSHKHARAM, H. SHEN, Q. CHENG}

\begin{tabular}{|c|c|}
\hline $\begin{array}{l}\text { 2,8,9-trihydroxy-1,3,5,7,9-cadinapentaen-14- } \\
\text { al;8-deoxy }\end{array}$ & Antifungal activity \\
\hline \multicolumn{2}{|l|}{ Phenols } \\
\hline Chlorogenic acid & Anti-oxidant and anti-mutagenic activity \\
\hline Gallic acid & Antioxidant activity, cytotoxic activity \\
\hline 4-hydroxybenzoic acid & $\begin{array}{l}\text { Anti-microbial activity, used a } \\
\text { preservative, oestrogenic activity, anti- } \\
\text { inflammatory and anti-oxidant activity }\end{array}$ \\
\hline Gossypol;(+)-from & Contraceptive and hypokalemic activity \\
\hline $3,3^{\prime}, 4^{\prime}, 5,7$-pentahydroxyflavan; (2S,3R)-form & Cytotoxic and phytotoxic activity \\
\hline $\begin{array}{l}3,3^{\prime}, 4^{\prime}, 5,7-\text {-pentahydroxyflavone; } 3^{\prime}-O-\beta-D- \\
\text { glucopyranoside }\end{array}$ & $\begin{array}{l}\text { Enzyme inhibitor, cytotoxic, anti-oxidant } \\
\text { activity }\end{array}$ \\
\hline Scopoletin & $\begin{array}{l}\text { Anti-spasmodic and anti-inflammatory } \\
\text { activity }\end{array}$ \\
\hline \multicolumn{2}{|l|}{ Fatty acids } \\
\hline 11,14-eicosadienoic acid & Hormonal activity \\
\hline Hexadecanoic acid & $\begin{array}{l}\text { Anti-microbial and anti-inflammatory } \\
\text { activity }\end{array}$ \\
\hline Octadecanoic acid & $\begin{array}{l}\text { Pharmaceutical excipient, surfactant } \\
\text { and softening activity }\end{array}$ \\
\hline 9-octadecenoic acid; (Z)-form & $\begin{array}{l}\text { Insecticidal, anti-bacterial and fungicidal } \\
\text { activity }\end{array}$ \\
\hline Tetradecanoic acid & $\begin{array}{l}\text { Defoaming agent, flavor adjuvant used } \\
\text { in food processing }\end{array}$ \\
\hline \multicolumn{2}{|l|}{ Carbohydrates } \\
\hline Cellulose & Capsule and tablet diluents \\
\hline \multicolumn{2}{|l|}{ Proteins } \\
\hline 3-phosphoglycerate phosphatase & Enzyme activity \\
\hline Vicilin & Anti-hypertensive activity \\
\hline
\end{tabular}

\section{CONCLUSION}

Cotton is one of the most important commercial crops and it is famous as white gold.

The stem bark is used in a preparation to strengthen the womb. The leaves are antipruritic, diuretic, and hypotensive. Leaves of the red variety of cotton are used for treating high blood pressure, abdominal cramps and pain, menstrual problems, painful ovaries, and difficult expulsion of afterbirth. The flower buds are used as an auricular analgesic. The seeds are crushed, and the juice given to babies as a treatment for thrush. The pressed cotton cake contains gossypol, which is used clinically as a male contraceptive. Gossypol is a toxic polyphenolic bisesquiterpene, which may have antifertility and antiviral properties. Cotton seed oil mostly extracted from Gossypium hirsutum and Gossypium herbaceum, that are also grown for cotton fiber and animal feed. It is extracted from cottonseed kernel, which are by-products of cotton fiber production.

Cottonseed oil is among the most unsaturated oils, others being safflower, corn, soybean, rapeseed and sunflower seed oils. Cottonseed oil 


\section{CULTIVATION OF COTTON IN CHINA AND IRAN}

has a ration of 2:1 of polyunsaturated to saturated fatty acids and generally consists of $65-70 \%$ unsaturated fatty acids including 18-24\% monounsaturated (oleic) and $42-52 \%$ polyunsaturated (linoleic), and 26-35\% saturated (palmitic and stearic).

The saturated fatty acids content make it a relatively stable vegetable oil without partial hydrogenation, so it is called as naturally hydrogenated oil. Cottonseed oil is described by scientists as being naturally hydrogenated because of the levels of oleic, palmitic, and stearic acids in it.

The major cottonseed oil's major benefits includes its high level of antioxidants, tocopherols that contribute to its long life on the shelf. Cottonseed oil is cholesterol free, as it extracted from plants which make it a great choice to reduce cholesterol level.

Cotton seed oil has high concentration of vitamin E, and its oil is more efficient for heart-healthy vitamin $\mathrm{E}$ than other vegetables oils, and as it is rich source of vitamin, which is like antioxidant, it is important in fighting free radicals and essential for good health like skin health, anti-aging, hair quality, and numerous illnesses including cancers.

It is obvious that the variety of traditional and modern medicinal uses of cotton is because of its active compounds that have been mentioned in different researches. With more control of the toxic effects of gossypol, applications on human health issues will increase.

\section{REFERENCES}

Albeltagy, A. M. (2014). Bt Transgenic Cotton: The world future of cotton production. Publisher: Lampert Academic Publisghing, DOI: 10.131 40/2.1.4937.9528

Amiel, E., Ofir, R., Dudai, N., Soloway, E., Rabinsky, T. \& Rachmilevitch, S. (2012). $\beta$-Caryophyllene, a compound isolated from the biblical balm gilead (Commiphora gileadensis), is a selective apoptosis inducer for tumor cell lines. Evid. Based Complement.Alternat.Med: 872394, DOI: 10.1155/2012/872394

An, T., Ouyang, W., Pan, W. et al. (2012). Amino acid derivatives of the (-) enantiomer of gossypol are effective fusion inhibitors of human immunodeficiency virus type 1 . Antivir.Res., 94(3): 276-287, DOI: 10.1016/j.antiviral.2012.02.014

Appiah, M.K., Feiker, T., Wiredu, A.N. \& Mamitimin, Y. (2014). Cotton production, land use change and resource competition in the AksuTarim river basin, Xinjiang, China. Q.J.Int.Agric., 53(3): 243-261.

Asinyo, B.K., Frimpong, C. \& Amankwah, E. (2019). The state of cotton production in Northern Ghana. The state of cotton production in Northern Ghana. Intern. Journal of Fiber and Textile Research, 5(4): 58-63.

Bellaloui, N., Stetina, S.R. \& Turley, R.B. (2015). Cottonseed protein, oil, and mineral status in near-isogenic Gossypium hirsutum cotton lines expressing fuzzy/linted and fuzzless/linted seed phenotypes under field conditions. Front. Plant Sci.,6: 137, DOI: 10.3389/fpls.2015. 00137

Buser, M. (2001). Extruding cotton gin byproducts to reduce chemical residues. J. Cotton.Sci., 5: 92-102.

Egbuta, M. A., Mclntosh, S., Waters, D.L.E., Vancov, T. \& Liu, L. (2017). 


\section{W. SUN, M.H. SHAHRAJABIAN, M. KHOSHKHARAM, H. SHEN, Q. CHENG}

Biological importance of cotton byproducts relative to chemical constituents of the cotton plant. Molecules, 22(1): 93, DOI: 10.3390/ molecules22010093

Ezuruike, U.F. \& Prieto, J.M. (2014). The use of plants in the traditional management of diabetes in Nigeria: Pharmacological and toxicological consideration. J.Ethnopharmacol., 155(2): 857-924, DOI: 10.1016/j.jep. 2014.05.055

Fryxell, P. A. (1979). The natural history of the cotton tribe (Malvaceae, tribe Gossypieae). College Station: Texas A \& M University Press.

Hegde, R.R., Dahiya, A., Kamath, M.G., Gao, X. \& Jangala, P.K. (2004). Cotton fibres. Tickle college of Engineering, University of Tennessee: Knoxville, TN, USA.

James, C. (2012). Global status of commercialized biotech/GM crops. ISAAA Briefs 44, Ithaca: ISAAA.

Khadi, B.M., Santhy, V. \& Yadav, M.S. (2010). Cotton: an introduction. In: Zehr UB, editor. Cotton biotechnology in agriculture and forestry. Berlin: Springer.

Khoshkharam, M., Shahrajabian, M. H., Sun, W. \& Cheng, Q. (2019). Survey the allelopathic effects of tobacco (Nicotiana tabacum L.) on cron (Zea mays L.) growth and germination. Cercet.Agron.in Moldova, 4(180): 332-340, DOI: 10.2478/cerce-2019-0032

Knox, O., Rochester, I., Vadakattu, G. \& Lawrence, L. (2006). Composting in Australian cotton production. Aust. Cotton Grow., pp. 46-48.

Koondhar, M.A., Qiu, L., Liu, X., Abbassi, F., Koondhar, M.A. \& Ge, H. (2018). Effects of market price, cultivating area and price regulation on cotton production in China. Afr.J.Agric.Res., 13(16): 858-865, DOI: $10.5897 / A J A R 2016.11072$

Mollaee, M., Mobli, A., Mutti, N.K., Manalil, S. \& Chauhan, B.S. (2019). Challenges and opportunities in cotton production. In book: Cotton production worldwide. Chapter 19, Publisher: Wiley-Blackwell, DOI: 10.1002/9781119385 523.ch18

Ogbaji, P.O., Li, J., Xue, X., Shahrajabian, M.H. \& Egrinya, E. A. (2018). Impact of bio-fertilizer or nutrient solution on spinach (Spinacea oleracea) growth and yield in some province soils of P.R. China. Cercet.Agron. in Moldova, 51(2): 43-52, DOI: 10.2478/cerce2018-0015

Pemsl, D.E., Orphal, J. \& Waibel, H. (2003). Bt-cotton productivity considerations from India and China. Conference on International Agricultural Research for Development, Gottingen, October 810, 2003.

Pishgar-Komleh, S.H., Sefeedpari, P. \& Ghahderijani, M. (2012). Exploring energy consumption and $\mathrm{CO}_{2}$ emission of cotton production in Iran. J.Renew.Sustain. Energy, 4(3): 033115, DOI: 10.1063/1.4727906

Polska, B., Segal, S.J., Baron, P.A., Gold, J.W., Ueno, H. \& Armstrong, D. (1989). Inactivation of human immunodeficiency virus in vitro by gossypol. Contraception, 39(6): 579587, DOI: 10.1016/0010-7824(89) 90034-6

Radhakrishnan, S. (2017). Sustainable cotton production. In book: Sustainable fibres and textiles, DOI: 10.1016/B978-0-08-102041-8.0 0002-0

Ratsula, K., Haukkamaa, M., Wichmann, K. \& Luukkainen, T. (1983). Vaginal contraception with gossypol: a clinical study. Contraception, 27(6): 571-576, DOI: 10.1016/0010-7824 (83) $90022-7$

Scull, E. (2008). Environmental Health Challenges in Xinjiang. Research brief produced as part of the China Environment Forum's partenship with Western Kentucky University on the USAID-supported China Environmental Health Poject.

Seagull, RW. \& Giavalis, S. (2004). Preand post-anthesis application of 


\section{CULTIVATION OF COTTON IN CHINA AND IRAN}

exogenous hormones alters fiber production in Gossypium hirsutum L. cultivar Maxxa GTO. J. Cotton Sci., 8: 105-111.

Shahrajabian, M.H., Sun, W. \& Cheng, Q. (2019a). A review of astragalus species as foodstuffs, dietary supplements, a traditional Chinese medicine and a part of modern pharmaceutical science. Appl.Ecol. Env.Res., 17(6): 13371-13382, DOI: 10.15666/aeer/1706_1337113382

Shahrajabian, M.H., Sun, W. \& Cheng, Q. (2019b). DNA methylation as the most important content of epigenetics in traditional Chinese herbal medicine. J.Med. Plant Res., 13(16): 357-369, DOI: 10.5897/JM PR2019.6803

Shahrajabian, M.H., Sun, W. \& Cheng, Q. (2019c). The influence of traditional Iranian and Chinese medicine on western and Islamic countries. AJMBR, 5(2): 94-99, DOI: 10.3329/ajmbr.v5i2.42490

Shahrajabian, M.H., Sun, W. \& Cheng, Q. (2019d). A review of ginseng species in different regions as a multipurpose herb in traditional Chinese medicine, modern herbology and pharmacological science. J.Med. Plant Res., 13(10): 213-226, DOI: 10.5897/JMPR2019. 6731

Shahrajabian, M.H., Sun, W. \& Cheng, Q. (2019e). Sustainable agriculture and soybean, a legume in traditional Chinese medicine with great biological nitrogen fixation. J.Biol. Environ.Sci., 13(38): 71-78.

Shahrajabian, M.H., Sun, W. \& Cheng, Q. (2019f). Chinese star anise and anise, magic herbs in traditional Chinese medicine and modern pharmaceutical science. AJMBR, 5(3): 162-179, DOI: 10.3329/ajmbr. v5i3.43584

Shahrajabian, M.H., Sun, W. \& Cheng, Q. (2020). Climate change, acupuncture and traditional Chinese herbal medicines. Pharmacogn. Common., 10(1): 57-59, DOI: 10.55 30/pc.2020.1.10

Shahrajabian, M.H., Sun, W. \& Cheng, Q. (2020). A short review of goji berry, ginger, ginseng and astragalus in traditional Chinese and Asian medicine. BSJ of Health Sci., 3(2).

Shavkat, H. \& Djanibekov, N. (2015). Improving cotton production and crop diversification in Uzbekistan: tradable cotton production targets. Conference: IAAE conference Agriculture in an Interconnected World, Milan, Italy.

Soleymani, A. \& Shahrajabian, M.H. (2018). Changes in germination and seedling growth different cultivars of cumin to drought stress. Cercet.Agron. in Moldova, 51(1): 91100, DOI: 10.2478/cerce-2018-0008

Stetina, S.R., Turley, R.B., Bellaloui, N. \& Boykin, J.C. (2014). Yield and fiber quality of five pairs of nearisogenic cotton (Gossypium hirsutum L.) lines expressing fuzzless/linted and fuzzy/linted seed phenotypes. J. Crop Improv., 28(5): 680-699, DOI: 10.1080/15427528. 2014.931901

Sun, W., Shahrajabian, M.H. \& Cheng, Q. (2019a). The insight and survey on medicinal properties and nutritive components of Shallot. J.Med Plant Res., 13(18): 452-457, DOI: 10.5897/JMPR2019.6836

Sun, W., Shahrajabian, M.H. \& Cheng, Q. (2019b). Anise (Pimpinella anisum I.), a dominant spice and traditional medicinal herb for both food and medicinal purposes. Cogent Biol., 5(1): 1-25, DOI: 10.1080/23312025.2019.1673688

Sun, W., Shahrajabian, M.H. \& Cheng, Q. (2019c). Therapeutic roles of goji berry and ginseng in traditional Chinese. J.Nutr. Food Sec., 4(4): 293-305.

Sun, W., Shahrajabian, M.H., Khoshkharam, M. \& Cheng, Q. (2020a). Adaptation of acupuncture and traditional Chinese herbal medicines models because of 
climate change. J. Stress Physiol. Biochem., 16(1): 85-90.

Sun, W., Shahrajabian, M.H. \& Cheng, Q. (2020b). Traditional Iranian and Arabic herbal medicines as natural anti-cancer drugs. Agrociencia, 54(1): 129-142.

Sun, W., Shahrajabian, M.H. \& Huang, Q. (2020c). Soybean seeds treated with single walled carbon nanotubes (SwCNTs) showed enhanced drought tolerance during germination. IJABBR, 8(1): 9-16, DOI: 10.33945/ SAMI/IJABBR.2020.1.2

UNEP (United Nations Environmental Program) (2002). Integrated assessment of trade liberalization and trade-related policies; a country study on the cotton sector in China. UNEP/ETB (2002/2004): People's Republic of China. Cotton and Annual Products. Gain Report Number: Ch11018. Public distribution. Prepared by M.N. Meador and W. Xinping. Approved by S. Sindelar, New York and Geneva.
Wendel, J.F., Brubaker, C.L. \& Seelanan, T. (2010). The origin and evolution of Gossypium. In: Stewart J.M. et al., Physiology of cotton. The Netherlands: Springer, pp.1-18.

Wilkins, T A. \& Arpat, A.B. (2005). The cotton fiber transcriptome. Physiol.Plant., 124: 295-300, DOI: 10.1111/j.1399-3054.2005.00514.x

Zeleke, M., Adem, M., Aynalem, M. \& Mossie, H. (2019). Cotton production and marketing trend in Ethiopia: a review. Cogent Food Agric., 5(1), 1691812, DOI: 10.1080/ 23311932.2019.1691812

Zhao, X. F. \& Tisdell, C. (2009). A comparative economic study of China's and Australia's cotton production. Economic Theory, Applications and Issues, Working paper No. 53, School of Economics, The University of Queensland, Brisbane, Australia.

Zhu, Z. (1991). A study on rational location of the cotton production in China. Chinese Geogr.Sci., 1(2): 129-140, DOI: $10.1007 / \mathrm{BF} 02664509$. 